\title{
Pengembangan Wisata Edukasi Berkelanjutan di Museum Geologi Bandung
}

\author{
Nadhia Maesari*1, Dadang Suganda², Cecep Ucu Rakhman ${ }^{3}$ \\ Magister Pariwisata Berkelanjutan \\ Sekolah Pascasarjana Universitas Padjadjaran, Indonesia ${ }^{1,2,3}$ \\ Email: nadhia.maesari19@gmail.com
}

\begin{abstract}
Geology Museum is a popular destination for educational tourism. But there are various obstacles so that in the implementation, educational tourism in Geological Museum has not been optimal so that need for the development of sustainable educational tourism model that can benefit both the visitors of the museum and the museum. Methods in this study using qualitative methods. Qualitative methods are used to obtain data based on factual conditions that occur, field observations, interviews and literature studies. The results in this study resulted in a new model for sustainable education in the Museum of Geology which refers to museum education policies, education and sustainable tourism indicators.
\end{abstract}

Keywords: Development, Educational Tourism, Sustainability, Museum.

\begin{abstract}
Abstrak
Museum Geologi merupakan destinasi populer wisata edukasi bagi para peserta didik. Namun terdapat berbagai kendala sehingga pada pelaksanaannya, wisata edukasi di Museum Geologi belum optimal sehingga perlu adanya pengembangan model wisata edukasi berkelanjutan yang dapat bermanfaat baik bagi pengunjung museum maupun museum itu sendiri. Metode dalam penelitian ini menggunakan metode kualitatif. Metode kualitatif digunakan untuk mendapatkan data berdasarkan pada kondisi faktual yang terjadi, observasi lapangan, wawancara danstudi literatur. Hasil dalam penelitian ini menghasilkan model baru untuk wisata edukasi berkelanjutan di Museum Geologi yang mengacu pada kebijakanpendidikan museum, indikator wisata edukasi dan pariwisata berkelanjutan.
\end{abstract}

Kata Kunci: Pengembangan Pariwisata; wisata edukasi; berkelanjutan, museum.

\section{A. PENDAHULUAN}

Museum Geologi merupakan museum yang menyediakan berbagai koleksi batuan, mineral dan fosil yang dikelola secara langsung oleh Kementerian Energi Sumber Daya Mineral (ESDM). Hal tersebut menjadikan Museum Geologi sebagai destinasi wisata yang terkenal di Kota Bandung, khususnya untuk melaksanakan wisata edukasi bagi berbagai jenjang sekolah. Museum Geologi didirikan pemerintah Hindia Belanda pada tahun 1912. Letaknya yang strategis, yakni berdekatan dengan Monumen Gedung Sate, yang merupakan ciri khas Kota Bandung, menjadikan Museum Geologi mudah ditemui. Setiap tahun jumlah kunjungan wisatawan didominasi oleh kunjungan sekolah.

Namun berdasarkan pengalaman dan pengamatan penulis ditemukan berbagai masalah. Kunjungan ke Museum Geologi belum mempunyai alur kunjungan yang terarah, sehingga menjadikan fungsi museum sebagai sarana pembelajaran belum dapat dimanfaatkan secara baik. Sebagian besar pengunjung pun hanya melihat sekilas tanpa adanya proses pembelajaran karena bahasa dan teks pada display Museum Geologi belum menyediakan informasi yang lengkap, sehingga pengunjung khususnya pelajar belum memahami materi yang terdapat pada benda koleksi. Hal tersebut berbanding terbalik 
dengan karakterisik museum yang baik, yaitu harus dapat menjadi jendela yang dapat memberi informasi kepada setiap pengunjungnya (Manlesu, 2013:1). Oleh karena itu Museum dianggap hal yang membosankan dan tidak menyenangkan. Hal tersebut didukung oleh hasil penelitian bahwa para peserta didik kurang bersemangat saat mengunjungi museum karena kurangnya daya tarik bagi peserta didik (Putra, 2015:15).

Tidak mudah untuk mengerti belajar di museum. Hal tersebut karena jumlah waktu yang dihabiskan di museum seringkali sangat singkat, terjadi dalam pembelajaran kelompok dan jarang terjadi (Hooper-greenhill, 2007:84). Dengan demikian harus ditemukan pendekatan pembelajaran yang pas dan menyenangkan untuk dilaksanakan di museum.

Pembelajaran Kontekstual akan cocok diterapkan untuk pembelajaran di museum. Pendekatan Pembelajaran Kontekstual merupakan pembelajaran yang mengaitkan antara materi yang dipelajari dengan kehidupan nyata (Komalasari, 2014:7). Model pembelajaran yang cocok akan membuat wisata edukasi di Museum Geologi lebih ideal dan menyenangkan.

Dilihat dari segi fasilitas multimedia yang terdapat di museum pun belum ditunjang dengan penjelasan dari staf museum. Pelajar yang menonton video pun masih bertanya-tanya tentang materi yang telah ditayangkan sehingga pengetahuan baru yang didapatnya pun belum terintegrasi dengan pengetahuan awal peserta didik. Oleh karena itu setiap staf museum yang bertugas harus benar-benar memahami materi yang diperlihatkan pada fasilitas multimedia tersebut. Selain itu peserta didik pun belum diberi kesempatan untuk bertanya.

Selain itu fasilitas umum yang dimiliki Museum Geologi juga belum begitu mendukung untuk ratusan pengunjung yang datang setiap harinya. Seharusnya berbagai fasilitas untuk jumlah orang banyak harus disediakan. Sejalan seperti yang dikatakan oleh Hooper (1994:67) bahwa "jika sebuah museum atau galeri ingin menarik sejumlah besar kelompok sekolah, fasilitas khusus harus disediakan. Mencakup toilet yang cukup untuk jumlah yang diharapkan, ruang untuk makan siang, ruang gantungan dan ruang di mana sepuluh kelompok atau lebih dapat bertemu di area display". Fasilitas-fasilitas tesebut tentunya sangat penting bagi sebuah museum. Belum adanya fasilitas yang memadai akan menghambat beberapa program wisata edukasi (Umah, 2014:18).

Wisata edukasi Museum Geologi seharusnya bukanlah sekedar kunjungan tahunan yang diadakan oleh guru. Ditambahkan oleh Hooper-Greenhill (2007) The research into school visits at the Tower of London also found that schools visited museums as part of a general culture of educational visits, trips and outings. Hal tersebut menunjukkan bahwa para guru belum mempunyai motivasi yang jelas saat membawa peserta didik ke museum.

Dalam pengertian sederhana wisata edukasi adalah suatu program dimana wisatawan berkunjung ke suatu lokasi wisata dengan tujuan utama untuk memperoleh pengalaman pembelajaran secara langsung di objek wisata tersebut (Rodger, 1998:28). Wisata edukasi adalah sebuah kegiatan yang biasanya dilaksanakan oleh institusi pendidikan, seperti sekolah dasar, sekolah menengah pertama dan sekolah menengah atas.

Seharusnya sesuai definisi wisata edukasi di atas, peserta didik yang berkunjung di Museum Geologi harus mendapatkan pengalaman pembelajaran secara langsung. Dimana peserta didik dapat memperoleh banyak pengetahuan dari objek-objek koleksi benda, informasi pada display koleksi dan fasilitas multimedia yang terdapat di Museum Geologi yang bermanfaat bagi pelajaran di sekolah maupun pengetahuan sehari-hari.

Jika hal ini dibiarkan maka kunjungan ke museum menjadi tidak ada proses pembelajaran sehingga tidak ada hasil yang dia dapat ketika pulang ke rumah. Museum pun akan kembali menjadi gudang statis penyimpanan artefak bahkan mati karena tidak adanya pengunjung museum. Untuk memastikan kelangsungan hidup sampai abad berikutnya, museum harus menunjukkan relevansi sosial dan 
penggunaannya dengan mengembangkan fungsi layanan publik mereka dan menjadi lebih berpengetahuan tentang kebutuhan pengunjung mereka dan lebih mahir dalam memberikan pengalaman yang menyenangkan dan bermanfaat.

Museum Geologi harus mempunyai sistem yang lebih terarah untuk wisata edukasi. Para peserta didik harus tetap belajar namun menyenangkan dan berbeda dengan belajar yang bisa mereka lakukan di sekolah setiap hari. learning is a serious activity that needs to be fun. In museums, learning seemed to nearly always be fun (Hooper-greenhill, 2007:187). Kesenangan hanya bisa dilakukan di atmosfir dimana peserta didik merasa diterima, nyaman di tempat dan tepat.

Selain membuat peserta didik nyaman dan senang, agar pembelajaran dalam museum dapat efektif. Museum Geologi juga harus dapat mengefektifkan sumber daya yang dimilikinya. Dengan demikian Museum Geologi akan menjadi museum yang berkelanjutan. Alcaraz, Hume and Sullivan Mort (2009) memberikan definisi kelestarian museum, yang digambarkan sebagai kemampuannya untuk memiliki "sumber daya yang memadai untuk mempertahankan keberadaan, dan memenuhi tujuannya hingga ke masa depan". Museum Geologi yang berkelanjutan akan dapat dinikmati oleh generasi masa depan jika dapat meninggalkan kesan yang baik dan intangible.

Kesan yang baik dan intangible museum sangat dibutuhkan dalam peningkatan minat pengunjung terhadap museum. Hal tersebut akan sangat menggugah minat pengunjung dan akan membuatnya ingin datang kembali lagi. Oleh karena itu inovasi-inovasi sangat diperlukan pada setiap daya tarik wisata untuk memuculkan kesan yang tidak terlihat itu. Khususnya Museum Geologi sebagai destinasi wisata edukasi pasti memerlukan pengembangan agar lebih banyak lagi pengunjung khususnya kunjungan sekolah yang datang. Inovasi dalam mengembangkan museum dapat menjadikan museum yang mandiri sehingga dapat menjadi tujuan wisata yang berkelanjutan.

Jika demikian, museum dapat dilihat sebagai situs yang kuat dan signifikan untuk tempat belajar saat ini dan masa depan. Disamping itu jika pengunjung sudah menganggap museum sebagai tempat wisata edukasi yang menyenangkan, mereka pun akan membantu museum melindungi fungsi utamanya sebagai penyimpan koleksi artefak untuk melestarikan nilai-nilai budaya.

\section{B. METODE PENELITIAN}

Penelitian ini menggunakan Metode Kualitatif. Metode kualitatif digunakan untuk mendapatkan data berdasarkan pada kondisi faktual yang terjadi, observasi lapangan, mendeskripsikan data yang berupa dokumen dan wawancara dengan informan (Bogdan \& Taylor, 1992). Informan juga dapat menggambarkan fenomena yang terjadi, hubungan sebab akibat, kecenderungan yang berkembang pada penelitian. Selain itu untuk mengukur wisata edukasi di Museum Geologi, indikator yang digunakan oleh peneliti yaitu atraksi, staf museum, infrastuktur dan fasilitas serta skenario pembelajaran kontekstual (perencanaan pariwisata).

\section{HASIL DAN ANALISIS}

Hasil dari penelitian ini adalah wisata edukasi di Museum Geologi belum berjalan secara optimal, baik dari segi atraksi, staf museum, fasilitas serta alur kunjungan yang diterapkan. Oleh karena itu pengembangan sangat penting dilakukan agar Museum Geologi dapat tetap eksis sebagai destinasi wisata edukasi yang populer di Kota Bandung.

Pengembangan wisata edukasi di Museum Geologi sangat perlu dilakukan untuk meningkatkan kemampuan museum dalam mengantisipasi perubahan yang direncanakan maupun tidak direncanakan di masa yang akan datang. Wisata edukasi juga merupakan wisata yang paling cocok untuk sebuah Museum Geologi, disamping karena jumlah kunjungan yang mayoritas peserta didik, fungsi utama 
museum juga sebagai edukasi. Sehingga wisata yang dilaksanakan museum pun terdapat kelebihan penambahan pengetahuan dan pemahaman, bukan sekedar rekreasi untuk bersenang-senang.

Hasil penelitian pun menunjukkan bahwa tingkat kunjungan ke Museum Geologi selalu dipadati oleh ratusan pengunjung setiap harinya. Menurut staf edukasi bahkan Museum Geologi pernah kedatangan 7000 pengunjung pada hari yang sama. Hal tersebut menunjukan bahwa museum geologi merupakan destinasi wisata edukasi yang biasa dikunjungi oleh berbagai jenjang sekolah.

Tabel 1 Data kunjungan Museum Geologi Tahun 2015-2017

\begin{tabular}{lccc}
\hline Pengunjung & $\begin{array}{c}\text { Tahun } \\
\mathbf{2 0 1 5}\end{array}$ & $\begin{array}{c}\text { Tahun } \\
\mathbf{2 0 1 6}\end{array}$ & $\begin{array}{c}\text { Tahun } \\
\mathbf{2 0 1 7}\end{array}$ \\
\hline TK & 566 & 721 & 656 \\
\hline SD/MI & 12.848 & 21.856 & 27.223 \\
\hline SMP/MTs & 66.063 & 69.732 & 87.990 \\
\hline SMA/ & 25.024 & 21.658 & 23.492 \\
SMK/MA & & & \\
\hline $\begin{array}{l}\text { Perguruan } \\
\text { Tinggi }\end{array}$ & 3.694 & 3.853 & 5.578 \\
\hline $\begin{array}{l}\text { Wisatawan } \\
\text { Umum }\end{array}$ & 14.878 & 18.776 & 23.043 \\
\hline Jumlah & 123.073 & 136.596 & 167.982 \\
\hline Sumber: Museum Geologi & &
\end{tabular}

Dari tabel 1 dapat disimpulkan bahwa kunjungan Museum Geologi meningkat setiap tahunnya dan didominasi oleh rombongan sekolah, khususnya peserta didik SMP/ MTs. Peserta didik yang datang ke museum pada umumnya merupakan paksaan dari guru karena program sekolah namun tidak jarangyang datang karena kemauan sendiri.

Model baru wisata edukasi berkelanjutan di Museum Geologi mempunyai tiga langkah penting, yaitu penerapan kebijakan pendidikan museum, penerapan indikator wisata edukasi museum yang ideal serta penerapan prinsip-prinsip pariwisata berkelanjutan. Model tersebut dapat menghasilkan museum yang mandiri, bertahan hingga generasi yang akan datang serta digemari oleh peserta didik bahkan pengunjung museum yang lain. Model baru wisata edukasi berkelanjutan ini dapat diterapkan di semua museum yang disesuaikan dengan sumber dayanya masing-masing.

\section{Pembahasan}

Museum Geologi harus mempunyai sistem yang lebih terarah untuk wisata edukasi. Para peserta didik harus tetap belajar namun lebih menyenangkan serta berbeda. Pengembangan wisata edukasi Museum Geologi pun akan berpengaruh terhadap keberlanjutan karena mempunyai manfaat-manfaat bagi pengunjung museum dan bagi museum itu sendiri.

Langkah pertama untuk pengembangan wisata edukasi berkelanjutan adalah menerapkan kebijakan pendidikan dengan disiplin. Berikut adalah kebijakan pendidikan yang dapat diterapkan di Museum Geologi (Thorhauge, 2014:56):

a. Manajemen Museum Geologi merumuskan serangkaian tujuan konkrit dari setiap ruang peraga utama untuk kegiatan pendidikan mereka. Didalamnya terdapat tujuan pembelajaran, catatan untuk staf museum atau guru pendamping, hasil pembelajaran yang akan dicapai setelah masuk ke ruangan tersebut dan curruiculum links dengan mata pelajaran yang terdapat di sekolah.

b. Manajemen Museum Geologi memperkuat kolaborasi mereka dengan sekolah dasar, sekolah menengah pertama, sekolah menengah atas, perguruan tinggi guru dan universitas tentang pengembangan kegiatan pendidikan mereka. Hal tersebut dilakukan untuk terus mengetahui 
perkembangan materi sekolah sehingga Staf Edukasi Museum Geologi dapat menyesuaikan materi pembelajaran museum dengan materi di sekolah.

c. Staf Museum Geologi menawarkan materi dan program pendidikan baik untuk sekolah dasar, sekolah menengah pertama dan sekolah menengah atas yang sesuai dengan kurikulum dan program pendidikan sekolah.

d. Staf Museum Geologi mengembangkan sumber belajar digital yang melengkapi kegiatan pendidikan mereka di museum dengan lebih baik lagi.

e. Staf Museum Geologi mengembangkan praktik evaluasi sistematis terhadap kegiatan pendidikan mereka. Hal tersebut penting dilaksanakan walaupun dari pihal sekolah sudah menyediakan lembar kerja siswa (LKS) sendiri. Dengan demikian museum dapat mengukur pengetahuan yang didapat peserta didik setelah berkunjung.

f. Staf Museum Geologi mengembangkan dan menarik perhatian potensi mereka sebagai sumber belajar dan informasi bagi peserta didik yang mengerjakan proyek sekolah.

g. Staf Museum Geologi mengembangkan penawaran mereka kepada guru mengenai bagaimana mereka dapat digunakan sebagai sumber belajar dan suplemen untuk pengajaran mereka. Walaupun Museum ini sudah banyak dikunjungi, Museum Geologi harus terus melakukan promosi bukan hanya menunggu ada sekolah yang reservasi.

Dengan melaksanakan kebijakan pendidikan di Museum, ini akan menjadi langkah pertama bagi pengembangan wisata edukasi di Museum Geologi. Museum Geologi dalam hal ini akan lebih mengetahui apa yang sebenarnya dibutuhkan pengunjung saat ini. Lebih dari itu akan terciptanya kolaborasi yang luar biasa antara Museum Geologi dan Sekolah.

Setelah menerapkan kebijakan pendidikan, Museum Geologi harus mengetahui indikator apa saja untuk menjadi destinasi wisata edukasi yang ideal. Indikator pertama adalah atraksi apa yang disediakan oleh museum, sebagai berikut (Ritchie, 2013:14):

a. Museum Geologi mampu menarik pengunjung agar ingin mengunjunginya.

b. Hal tersebut dapat dilakukan Museum Geologi dengan menyebarkan kuesioner kepada masyarakat tentang kunjungan museum. Dalam hal ini Museum Geologi dapat menyebarkan kuesioner ke sekolah-sekolah sambil melaksanakan sosialisasi tentang apa saja yang terdapat di museum sehingga pihak sekolah atau para pesesrta didik tertarik untuk mengunjungi museum.

c. Museum memiliki keunikan dari museum lainnya

d. Museum Geologi memiliki keunikan dari museum lainnya karena benda koleksinya. Museum Geologi bahkan Museum Geologi Bandung merupakan satu-satunya Museum Geologi di Indonesia dan terbesar di Asia Tenggara. Oleh karena itu dengan keunikannya Museum Geologi harus mengemasnya agar terlihat lebih menarik. Misalnya Dinosaurus yang merupaka ikon Museum, harus dapat perlakukan khusus seperti ditambah efek gerak dan suara agar hal tersebut dapat menjadikan hal yang tidak terlupakan oleh pengunjung museum, khususnya peserta didik.

e. Materi pembelajaran yang terdapat pada museum sesuai dengan tema museum (Kegeologian).

f. Museum Geologi mempunyai kelompok fungsional yang bertugas untuk meneliti dan mencari benda-benda peninggalan geologi sehingga benda koleksi yang disuguhkan museum pun selalu konsisten dengan tema museum.

Indikator wisata edukasi yang kedua adalah para sumber daya manusia atau staf yang terdapat dari museum itu sendiri. Sumber daya manusia yang paling menentukan bagaimana museum itu dapat berjalan dengan baik dengan kriteria sebagai berikut:

a. Staf Museum Geologi dapat mengatur alur kunjungan secara beraturan dan terarah sesuai dengan skenario yang ditentukan. 
b. Mengatur alur kunjungan merupakan tugas dari staf museum khususnya bagian pemanduan. Museum Geologi tentu harus menentukan dan melaksanakan alur kunjungan agar pengunjung dengan jumlah besar dapat menerima informasi museum secara tertib dan teratur. Alur kunjungan tersebut harus terdapat tempat-tempat yang dikunjungi serta kegiatan apa saja yang dilaksanakan pada tempat tersebut.

c. Staf Museum Geologi dapat memperlakukan koleksi museum secara terarah dan terkendali.

d. Dengan adanya staf museum di bagian dokumentasi dan konservasi, Maka koleksi museum harus diperlakukan sesuai dengan prinsip-prinsip pelestarian terhadap warisan budaya.

e. Staf Museum Geologi dapat menyediakan informasi pada display koleksi dalam bahasa dan teks yang dapat dipahami pengunjung khususnya peserta didik.

f. Tidak dapat dipungkiri lagi bahwa sebagian besar pengunjung Museum Geologi adalah peserta didik baik dari jenjang sekolah dasar, sekolah menengah pertama maupun sekolah menengah atas. Dengan demikian agar wisata edukasi dapat berjalan dengan lancar, deskripsi pada benda koleksi harus disesuaikan dengan bahasa yang sesuai dengan umur mereka. Deskripsi benda koleks tersebut dapat membuat salah paham apabila bahasa yang digunakan terlalu berat untuk mereka.

g. Staf Museum Geologi dapat menjelaskan materi kepada peserta didik dan membantu guru dalam melaksanakan wisata edukasi.

h. Staf Museum Geologi khususnya bagian Edukasi harus mempunyai kualifikasi komunikasi yang baik serta dituntut memiliki kompetensi pengetahuan luas dan mendalam mengenai sejarah, budaya, atraksi, serta seluruh fasilitas yang berada di Museum Geologi agar dapat menjelaskan kepada peserta didik dan menjawab pertanyaan-pertanyaan yang diajukan oleh peserta didik.

i. Staf Museum Geologi merumuskan tujuan pembelajaran dari setiap ruangan.

j. Walaupun di Museum Geologi mempunyai empat ruang peraga utama yang diatur sesuai dengan tema (tematik), staf museum harus merumuskan tujuan pembelajaran secara tertulis baik di brosur maupun di web seperti yamg tertera dalam kebijakan pendidikan. Hal tersebut dapat memudahkan guru untuk mempersiapkan peserta didiknya sebelum mereka berangkat untuk wisata edukasi di Museum Geologi.

Indikator wisata edukasi yang ketiga adalah fasilitas yang terdapat di Museum Geologi. Untuk menjadikan Museum Geologi sebagai destinasi wisata edukasi maka fasilitas yang harus dimiliki adalah (Hooper-Greenhill, 1994:106):

a. Museum Geologi memiliki Auditorium dengan sarana dan prasarana yang lengkap.

b. Auditorium dengan sarana dan prasarana yang lengkap dibutuhkan oleh setiap museum tak terkecuali Museum Geologi. Auditorium dalam museum berfungsi untuk memutar film yang berdurasi cukup lama dengan penerangan yang dapat disesuaikan dengan kebutuhan. Museum Geologi selalu dipadati jumlah kunjungan yang sangat banyak maka jumlah kapasitasnya pun harus mengimbangi rata-rata peserta didik yang mengunjunginya.

c. Museum Geologi memiliki ruang edukasi untuk tempat bertukar pikiran (refleksi materi) antara peserta didik maupun dengan guru dan staf museum.

d. Ruang edukasi Museum Geologi harus dipergunakan oleh peserta didik yang datang ke museum. Selain untuk melakukan refleksi materi, ruang edukasi dapat dilakukan untuk workshop yang berkaitan dengan kegeologian. Sama halnya dengan Auditorium, ruang edukasi juga harus memperhatikan jumlah kapasitasnya.

e. Museum Geologi memiliki jumlah toilet yang cukup untuk jumlah peserta didik yang banyak.

f. Memiliki jumlah toilet yang cukup belum cukup untuk sebuah museum. Toilet museum pun harus dijamin kebersihannya. Toilet bersih di museum memiliki nilai strategis agar pengunjung yang berwisata ke museum tidak kecewa dengan kondisi toiletnya (Susantio, 2017) 
g. Museum Geologi mempunyai ruangan besar untuk berkumpul peseta didik.

h. Selain Auditorium dan Ruang edukasi, museum geologi pun harus mempunyai ruangan besar dimana ratusan peserta didik bisa berkumpul dan beristirahat. Hal tersebut dinilai sepele padahal ruangan tersebut sangat penting untuk menunjang peserta didik yang berasal dari luar kota.

i. Museum Geologi memiliki ruang ganti untuk peserta didik.

j. Museum Geologi telah mempunyai klinik bagi pertolongan pertama bagi yang membutuhkan. Namun peneliti tidak menemukan ruang ganti untuk peserta didik dibutuhkan pula untuk peserta didik yang berasal dari luar kota.

Museum yang memiliki fasilitas yang baik dan lengkap akan membuat pengunjung khususnya pihak sekolah tertarik untuk datang lagi. Mereka akan membawa peserta didik yang berbeda setiap tahunnya.

Indikator wisata edukasi yang terakhir adalah perencana pariwisatanya. Peneliti melihat hal tersebut dari bagaimana mereka merancang skenario kegiatan yang ideal untuk wisata edukasi. Skenario kegiatan atau yang biasa disebut alur kunjungan pada model baru wisata edukasi ini mengacu pada pembelajaran kontekstual, dimana peserta didik tidak lagi hanya melihat-lihat tanpa tujuan yang jelas. Berikut adalah rinciannya (Komalasari, 2014):

a. Kontruktivisme; Peserta didik dan Guru pendamping diajak Staf museum berkeliling museum sambil dijelaskan materi terkait.

b. Inkuiri; Staf museum dibantu guru meminta peserta didik untuk memberikan contoh-contoh benda yang mirip dengan macam-macam benda yang ada disekitar lingkungan museum.

c. Bertanya; Peserta didik diberi kesempatan bertanya seputar materi kepada Guru/ Staf Museum.

d. Belajar kelompok; Peserta didik diberi kesempatan untuk berdiskusi dengan temannya atau bertanya pada Staf museum.

e. Pemodelan; Peserta didik diberikan suatu multimedia seperti film untuk membangun pemahaman konsep materi, dan memotivasi peserta didik untuk berperan aktif dalam kegiatan pembelajaran.

f. Refleksi; Staf Museum menjelaskan kembali dan memberikan kesimpulan atas apa saja yang telah dipelajari pada materi.

g. Penilaian nyata; Peserta didik diberi tugas untuk menyerap informasi dari staf dan diberi pekerjaan rumah untuk memberikan laporan. Dengan demikan guru akan memahami seberapa besar perkembangan peserta didik dalam belajar.

Pembelajaran kontekstual merupakan pembelajaran yang sangat cocok digunakan di museum. Pendekatan kontekstual dalam pembelajaran di Museum, berusaha untuk mengubah kondisi wisata edukasi yang tidak ideal, yaitu dengan membuat skenario pembelajaran atau alur kunjungan yang dimulai dari konteks kehidupan nyata siswa (daily life). Peserta didik yang berkunjung akan dapat menerima informasi yang sesungguhnya sesuai dengan tujuan pembelajaran yang diharapkan.

Menerapkan pembelajaran kontekstual bukan mudah bagi guru maupun peserta didik, oleh karena itu agar pelaksanaan pembelajaran kontekstual berhasil dengan baik, guru perlu meningkatkan kemampuannya dengan menguasai pendekatan- pendekatan pembelajaran yang menempatkan siswa sebagai pusat pembelajaran, dan guru sebagai fasilitator yang tetap mengontrol jalannya pembelajaran (Hutagaol, 2013:6).

Melalui skenario baru dalam pembelajaran di museum diharapkan dapat meningkatkan kualitas pembelajaran di museum yang akhirnya dapat meningkatkan motivasi dan minat belajar peseta didik dalam mengunjungi museum, yang pada akhirnya mereka dapat meningkatkan hasil belajar.

Setelah menerapkan kebijakan pendidikan, dan memenuhi indikator wisata edukasi, langkah yang ketiga yaitu menerapkan prinsip-prinsip pariwisata berkelanjutan. Pariwisata berkelanjutan dapat diterapkan di seluruh jenis wisata termasuk wisata edukasi. Wisata edukasi yang menerapkan prinsip- 
prinsip pariwisata berkelanjutan tentu akan berimbas baik terhadap museum. Berikut prinsip-prinsip pariwisata berkelanjutan yang dapat diterapkan (Davies \& Wilkinson, 2016):

a. Manajemen Museum Geologi menghargai dan melindungi lingkungan alam dan budaya dan peka terhadap dampak museum dan pengunjungnya khususnya peserta didik. Pengembangan yang dilakukan oleh museum jangan sampai merusak lingkungan dan budaya museum. Menghargai dan melindungi lingkungan alam dan budaya dapat dilakukan museum dengan cara belajar bagaimana mempertahankan kondisi untuk pelestarian koleksi tanpa ketergantungan berlebihan pada penggunaan energi dan memperlakukan koleksi sesuai dengan prinsip kebudayaan (Davies \&Wilkinson, 2016).

b. Manajemen Museum Geologi berusaha untuk mencapai yang terbaik, membangun hubungan jangka panjang yang dalam dengan berbagai khalayak termasuk pihak sekolah. Walaupun Museum Geologi selalu dikunjungi oleh ratusan bahkan ribuan peserta didik, namun jangan putus kontak dengan sekolah-sekolah yang pernah mengunjunginya. Hal ini termasuk pada keberlanjutan sosial, dima museum dan sekolah dapat terus menjaga hubungannya.

c. Manajemen Museum Geologi mengakui warisan yang diberikan oleh generasi sebelumnya dan menyampaikan warisan koleksi, informasi, dan pengetahuan yang lebih baik ke generasi berikutnya. Sesuai dengan kebijakan pendidikan museum di atas, museum harus terus menyesuaikan materi pembelajaran di museum dengan pembelajaran di sekolah sehingga sesuai dengan kebutuhan pengunjung saat ini.

d. Manajemen Museum Geologi mengelola koleksi dengan baik, sehingga akan menjadi aset berharga bagi generasi mendatang. Staf harus selalu melakukan perawatan bagi benda-benda koleksi museum sehingga terhindarnya dari kerusakan benda koleksi.

e. Manajemen Museum Geologi terus memanfaatkan sebaik-baiknya energi dan sumber daya alam lainnya dan kurangi limbah. Keberlanjutan lingkungan sangat penting dalam pariwisata berkelanjutan. Museum geologi harus turut serta untuk mempergunakan dan menghemat energi dalam pemeragaan benda museum. Selain itu museum harus mendidik pengunjung yang datang agar ikut melestarikan lingkungan museum dengan memasang label-label hemat energi.

f. Manajemen Museum Geologi mempertimbangkan potensi untuk menunjukkan dan mendorong pembangunan berkelanjutan. Kepala museum harus paham terhadap pariwisata berkelanjutan, sehingga mengambil keputusan pun sesuai dengan prinsip-prinsip pariwisata berkelanjutan.

g. Manajemen Museum Geologi berkontribusi secara bertanggung jawab terhadap vitalitas sosial, budaya dan ekonomi daerah setempat dan dunia yang lebih luas. Walaupun Museum Geologi selalu dibantu oleh anggaran pemerintah, namun jika ingin berkelanjutan Museum Geologi juga harus berusaha agar menjadi museum yang mandiri tanpa mengandalkan pemerintah. Bantuan dapat kapan saja di berhentikan, sehingga museum tetap harus mandiri.

h. Manajemen Museum Geologi terus kembangkan kapasitas staf. Museum harus memberikan pelatihan-pelatihan, seminar atau workshop kepada staf agar ilmu dan keahlian mereka dapat berkembang sesuai dengan perkembangan zaman.

i. Manajemen Museum Geologi menanggapi perubahan konteks politik, sosial, lingkungan dan ekonomi dan memiliki tujuan jangka panjang yang jelas yang mencerminkan harapan masyarakat terhadap museum.

j. Manajemen Museum Geologi membuat rencana jangka panjang, untuk mempertimbangkan sepenuhnya pembangunan berkelanjutan dalam semua aktivitas dan kebijakan mereka dan kerjakan dalam sumber daya yang ada. Ciri berkelanjutan adalah memikirkan masa depan sehingga tidakakan seenaknya mengambil keputusan yang instan hanya untuk masa kini. 
k. Manajemen Museum Geologi bersinergi dengan museum lain, dan organisasi lainnya, dalam kemitraan. Hal ini sangat penting demi bangkitnya museum-museum di Indonesia yang sudah hampir mati. Kegiatan ini juga dapat menjadi sarana untuk bertukar pikiran sesama petugas museum demi kemajuan museum-museum di Indonesia.

Menerapkan prinsip-prinsip pariwisata berkelanjutan memang tidak mudah dan harus ada kerjasama dari seluruh tim museum. Namun dengan kesungguhan dalam menerapkan prinsip-prinsip ini akan berbuah manis di masa yang akan datang.

Dengan demikian model baru untuk wisata edukasi berkelanjutan di museum adalah dengan menerapkan kebijakan pendidikan museum, indikator wisata edukasi dan prinsip-prinsip pariwisata berkelanjutan. Model wisata edukasi berkelanjutan ini akan membuat wisata edukasi berjalan lancar dan bukan sekedar kunjungan rutin para peserta didik yang dipaksa guru untuk melaksanakan program sekolah.

Model wisata edukasi ini tentu dapat pula diterapkan di museum-museum lain selain Museum Geologi. Model ini akan membantu museum-museum dalam melakukan perubahan atau pengembangan agar masyarakat tertarik datang ke museum-museum yang ada di Indonesia.

\section{SIMPULAN}

Model baru wisata edukasi berkelanjutan di Museum Geologi mempunyai tiga langkah penting, yaitu penerapan kebijakan pendidikan museum, penerapan indikator wisata edukasi museum yang ideal serta penerapan prinsip-prinsip pariwisata berkelanjutan. Model tersebut dapat menghasilkan museum yang mandiri, bertahan hingga generasi yang akan datang serta digemari oleh peserta didik bahkan pengunjung museum yang lain. Model baru wisata edukasi berkelanjutan ini dapat diterapkan di semua museum yang disesuaikan dengan sumber dayanya masing-masing.

\section{DAFTAR REFERENSI}

Alcaraz, C., Hume, M., \& Mort, G. S. (2009). Creating sustainable practice in a museum context: Adopting service-centricity in non-profit museums. Australasian Marketing Journal, 17(4), 219-225. https://doi.org/10.1016/j.ausmj.2009.06.003

Bogdan, Robert C. Dan Steven J. Taylor, 1992, Introduction to Qualitative Research Methotds: A Phenomenological Approach in the Social Science. alih bahasa Arief Furchan, John Wiley dan Sons, Surabaya, Usaha Nasional.

Davies, M., \& Wilkinson, H. (2016). Sustainability and Museum, 29(3), 59-70. https://doi.org/10.1007/978-3-319-12964-8

Hooper-greenhill, E. (2007). Museums and Education: Purpose, pedagogy, performance (1st ed.). Newyork: Routledge.

Hooper-Greenhill, E. (1994). Museums and their visitors. Newyork: Routledge.

Hutagaol, K. (2013). Pembelajaran Kontekstual untuk Meningkatkan Kemampuan Representasi Matematis Siswa Sekolah Menengah Pertama. Jurnal Ilmiah Program Studi Matematika STKIP Siliwangi Bandung, 2(1), 85-99.

Komalasari, K. (2014). Pembelajaran Kontekstual Konsep dan Aplikasi. Bandung: Refika Aditama.

Manlesu, Agnes (2013). Pengembangan Media Informasi Pada Museum Daerah Kabupaten Banggai. Tesis Universitas Padjadjaran.

Putra, M.S (2015). Persepsi Wisatawan SLTP Tentang Museum Sang Nila Utama Provinsi Riau $t$ (Vol. 4). https://doi.org/10.1525/aa.1993.95.4.02a00690

Ritchie, Brent. W. (2003). Managing Educational Tourism. Britain:Cromwell Press

Rodger, 1998. Leisure, Learning and Travel, Journal of Physical Education, 69 (4): hal 28

Susantio, D. (2017) Toilet, Salah Satu Nyawa Museum. Diakses pada 17 Mei 2018. Tersedia di: https://www.kompasiana.com/djuliantosusantio/toilet-salah-satu-nyawamuseum_596e91bf880ecd465d50f4b3 
Thorhauge, S. (2014). Interface Learning - New Goals for Museum and Upper Secondary School Collaboration.

Umah, R. A. (2014). Strategi Museum Perjuangan Kota Yogyakarta 